Review

\title{
Absorption of Vitamin A and Carotenoids by the Enterocyte: Focus on Transport Proteins
}

\section{Emmanuelle Reboul ${ }^{1,2,3}$}

1 INRA, UMR1260, Nutrition, Obesity and Risk of Thrombosis, Marseille F-13385, France;

E-Mail: Emmanuelle.Reboul@univ-amu.fr; Tel.: +33-4-91-29-41-03; Fax: +33-4-91-78-21-01

2 INSERM, UMR1062, Marseille F-13385, France

3 Aix-Marseille University, Marseille F-13385, France

Received: 24 June 2013; in revised form: 19 August 2013 / Accepted: 26 August 2013 /

Published: 12 September 2013

\begin{abstract}
Vitamin A deficiency is a public health problem in most developing countries, especially in children and pregnant women. It is thus a priority in health policy to improve preformed vitamin A and/or provitamin A carotenoid status in these individuals. A more accurate understanding of the molecular mechanisms of intestinal vitamin $\mathrm{A}$ absorption is a key step in this direction. It was long thought that $\beta$-carotene (the main provitamin $A$ carotenoid in human diet), and thus all carotenoids, were absorbed by a passive diffusion process, and that preformed vitamin A (retinol) absorption occurred via an unidentified energy-dependent transporter. The discovery of proteins able to facilitate carotenoid uptake and secretion by the enterocyte during the past decade has challenged established assumptions, and the elucidation of the mechanisms of retinol intestinal absorption is in progress. After an overview of vitamin A and carotenoid fate during gastro-duodenal digestion, our focus will be directed to the putative or identified proteins participating in the intestinal membrane and cellular transport of vitamin A and carotenoids across the enterocyte (i.e., Scavenger Receptors or Cellular Retinol Binding Proteins, among others). Further progress in the identification of the proteins involved in intestinal transport of vitamin A and carotenoids across the enterocyte is of major importance for optimizing their bioavailability.
\end{abstract}

Keywords: retinol; carotenes; xanthophylls; bioavailability; transporters; intestinal absorption 


\section{List of abbreviations}

ARAT: Acyl-CoA Acyl Transferase; ABCA1: ATP Binding Cassette A1; ABCG5: ATP Binding Cassette G5; ABCG8: ATP Binding Cassette G8; BBM: Brush Border Membrane; BCMO1: $\beta$-carotene-15,15'-monooxygenase; $\mathrm{BCDO} 2$ : $\beta$-carotene-9',10'-dioxygenase; CBP: Carotenoid-Binding protein; CD36: Cluster Determinant 36; CRBPII: Cellular Retinol Binding Protein II; HR-LBP: Human Retinal Lutein-Binding Protein; ISX: Intestine-Specific Homebox; L-FABP: Liver Fatty-AcidBinding Protein; LRA: Lecithin Retinol Acyl Transferase; NPC1L1: Niemann-Pick C1-Like 1; RBP: Retinol Binding Protein; RBPR2: RBP-receptor 2; SR-BI: Scavenger Receptor class B type 1; STRA6: STimulated by Retinoic Acid 6.

\section{Introduction}

Vitamin A is essential for normal cell growth, cell differentiation, immunological functions and vision [1]. However, vitamin A deficiency is still a public health problem in more than half of all countries, especially in Africa and South-East Asia where meat intake is low, and particularly in young children and pregnant women. Therefore, it is a priority in health policy to improve preformed vitamin A and/or provitamin A carotenoid status of these population subgroups. A precise understanding of the molecular mechanisms involved in vitamin A intestinal absorption is a key step in this direction.

Vitamin A is found in animal-based foods as retinyl esters (mainly retinyl palmitate). In fruits and vegetables, it occurs as provitamin A carotenoids (mainly $\beta$-carotene, $\alpha$-carotene and $\beta$-cryptoxanthin), which can be cleaved and metabolized into retinol after absorption by the intestinal cells (Table 1). Nonprovitamin A carotenoids, such as lutein and lycopene, share similar digestion/absorption pathways with provitamin A carotenoids: they will thus be included in this review when appropriate (Table 1). The fundamental mechanisms of preformed vitamin A and carotenoid absorption were first studied 40 years ago using rat everted intestinal sacs [2-4]. The data obtained suggested that carotenoids were absorbed by passive diffusion, while preformed A was absorbed via (a) carrier-dependent proteins. Recent studies completed over the past ten years have once again addressed these hypotheses, and have shown that the mechanisms of retinol and carotenoid absorption are actually more complex than previously thought. Although a passive diffusion may occur at pharmacological concentrations of these compounds, a protein-mediated transport is clearly involved at dietary doses.

After an overview of the fate of retinol and carotenoid in the human upper gastrointestinal lumen, we will focus on the putative or identified proteins participating in the intestinal membrane and cellular transport of vitamin A and carotenoids across the enterocyte identified until 2013.

\section{Overview of Vitamin A and Carotenoid Fate during the Digestion Process}

Fat-soluble micronutrients including vitamin A and carotenoids are assumed to follow the fate of lipids in the upper gastrointestinal tract [5], and their absorption presumably occurs in the upper half of the small intestine. 
Table 1. Main dietary retinoids and carotenoids.

\begin{tabular}{|c|c|c|c|}
\hline & Molecular structure & $\begin{array}{l}\text { Main food sources } \\
(\mu \mathrm{g} / \mathbf{1 0 0} \mathrm{g})[6-9]\end{array}$ & $\begin{array}{c}\text { Transport } \\
\text { proteins in the } \\
\text { enterocyte }\end{array}$ \\
\hline Retinol & & \multirow{2}{*}{$\begin{array}{l}\text { Liver: } 10,800-23,500 \\
\text { Fatty fish: } 800-1000 \\
\quad \text { Butter: } 700\end{array}$} & $\begin{array}{l}\text { CRBPII, } \\
\text { possibly } \\
\text { ABCA1 }\end{array}$ \\
\hline $\begin{array}{l}\text { Retinyl } \\
\text { palmitate }\end{array}$ & & & \\
\hline$\beta$-carotene & & $\begin{array}{c}\text { Raw carrot: } 8840 \\
\text { Canned carrot: } 5780 \\
\text { Cooked spinach: } 5240\end{array}$ & \multirow{3}{*}{ SR-BI, CD36 } \\
\hline$\alpha$-carotene & & Cooked carrot: 468 & \\
\hline$\beta$-cryptoxanthin & & $\begin{array}{c}\text { Orange juice: } 880 \\
\text { Mandarin juice: } 920\end{array}$ & \\
\hline Lutein & & $\begin{array}{c}\text { Cooked spinach: } 7040 \\
\text { Lettuce: } 2640\end{array}$ & $\begin{array}{l}\text { SR-BI, } \\
\text { NPC1L1, } \\
\text { possibly } \\
\text { ABCG5 }\end{array}$ \\
\hline Lycopene & & $\begin{array}{c}\text { Tomato sauce: } 15,920 \\
\text { Tomatoes: } 3030 \\
\text { Watermelon: } 4870\end{array}$ & SR-BI \\
\hline
\end{tabular}

The first phase of the process of digestion/absorption is the dissolution of carotenoids [10,11] and vitamin A [12] in the fat phase of the meal. This phase is emulsified into lipid droplets in the stomach and duodenum. The size of the droplets has apparently no effect on the efficiency of the absorption of vitamin A in healthy humans, and no degradation or absorption of vitamin A has been detected at the stomach level [11,12].

It seems that only the free forms of fat-soluble vitamins and carotenoids are absorbed by the intestinal mucosa, suggesting that the esterified forms are first hydrolyzed. Studies on this topic mainly concern retinyl esters. Their hydrolysis may begin in the stomach, where gastric lipase hydrolyses about $17.5 \%$ of the triacylglycerols [13]. However, the data obtained in healthy subjects have shown that gastric lipase does not significantly hydrolyse retinyl palmitate [12]. The hydrolysis of esters of vitamin A thus occurs essentially in the duodenum. The pancreatic juice contains two main enzymes that could perform this hydrolysis: cholesterol ester hydrolase (CEH) and pancreatic lipase (LP). It has been shown that the $\mathrm{CEH}$ can achieve this hydrolysis in vitro [14-17]. However, studies in CEH-deficient mice showed that this enzyme was not significantly involved in the hydrolysis of retinyl esters in vivo $[18,19]$. Since some studies showed that the LP could hydrolyse retinyl palmitate in vitro [18,20-22] and as the CEH was not involved, it is assumed that the luminal hydrolysis of 
retinyl esters is achieved by the LP, together with the pancreatic lipase-related protein 2 [22]. The enzymes described above are all good candidates for the hydrolysis of esters of carotenoids. In a study on the bioavailability of lutein esters, it was suggested that $\mathrm{CEH}$ could allow the release of free lutein [17]. The esters that have not been hydrolyzed by LPs or CEH may be cleaved by mucosal enzymes, given that a retinyl ester hydrolase probably due to a phospholipase B [23] was identified at the brush border membrane (BBM) level of rat and human intestine [24,25]. Finally, it is conceivable that some esters are taken up intact by the intestinal cell and hydrolyzed intracellularly [8].

During the process of digestion, carotenoids and fat-soluble vitamins are incorporated with other lipids into the mixed micelles [5], presumably necessary for their absorption by the enterocyte. Mixed micelles are a mixture of phospholipids, cholesterol, lipid digestion products (such as free fatty acids, monoacylglycerols and lysophospholipids) and bile salts. Fat-soluble micronutrient transfer to mixed micelles during dietary lipid lipolysis by the gut lipases can be affected by several factors, including the micronutrient molecular structure [5,26], $\mathrm{pH}$ and bile lipid concentration [27,28], and the presence of a minimal amount of dietary fat [29]. Dietary fat stimulates pancreatic juice and biliary secretion, both necessary for lipid digestion and micelle formation, and provide the lipids necessary to structure the mixed micelles. It is assumed that the higher the percentage of lipid micronutrient incorporated in micelles (a percentage called "bioaccessibility"), the higher its absorption efficiency. Although it is assumed that retinol and carotenoids globally transfer to the mixed micelles, some may be incorporated into other proteic or lipid structures (vesicles and liposomes) present in the same aqueous fraction. It has been shown that vitamin A can be incorporated in phospholipid bilayers [30,31] and that vesicle stability to the bile salt deoxycholate is enhanced by the presence of vitamin A [30]. Also, $\beta$-lactoglobulin, a lipocalin recovered in cow milk, is able to bind both retinol and $\beta$-carotene [32-35]. It is therefore possible that some proteins found in the diet and/or the pancreatic/biliary secretions bind a fraction of retinol and/or carotenoids and transport them to the brush border membrane (BBM) of the enterocyte. The mechanisms of absorption may then depend on their associated vehicles. In the case of mixed micelles, the particles are isolated from the rest of the intestinal contents in the unstirred water layer of the glycocalyx area and dissociated by $\mathrm{pH}$ effect. Indeed, the acidic microclimate of this area promotes the protonation of fatty acids. This phenomenon reduces fatty acid solubility in micelles, causing their release and thus micelle dissociation near the BBM. Components released are then picked up by various more or less specific systems responsible for their uptake by the enterocyte.

Retinol absorption efficiency ranges between 75\% [36] and 100\% [37-42]. Absorption efficiency of $\beta$-carotene ranges from $3 \%$ to $90 \%$ for [43-45]. Nevertheless, it is assumed that retinol displays a higher absorption efficiency than carotenoids, as confirmed by recent data obtained in our laboratory using Caco-2 cells. Micellar retinol absorption efficiency was around 30\% in $1 \mathrm{~h}$, but less than 5\% for micellar provitamin A carotenoids [46]. This may be explained by the presence of an efficient specific transporter for retinol, whereas provitamin A carotenoids are absorbed via non-specific transporters (see below). 


\section{Absorption of Vitamin A and Carotenoids by the Enterocyte (Figure 1)}

\subsection{Apical Uptake and Efflux}

Although some authors have suggested that free retinol (from 0.5 to $130 \mu \mathrm{M}$ ) enters intestinal cells by simple diffusion [47], it has long been acknowledged that retinol uptake occurs by a saturable carrier-mediated process at physiological doses, whereas it occurs by passive diffusion at pharmacological doses in Caco-2 cells [48] and in rats [2,4]. A good candidate for retinol specific uptake by intestinal cells was the protein STRA6 (STimulated by Retinoic Acid 6). This 74 kDa multi-transmembrane transporter has been identified as a specific receptor for RBP (Retinol-Binding Protein) [49]. Among other tissues, this protein is found in the intestine during development, although it is not clear whether it persists in adults [50]. Even so, it can still be suggested that STRA6 may be responsible for the uptake of either micellar retinol or retinol bound to protein-like $\beta$-lactoglobulin (see Section 1), especially because this protein shares similar amino acid sequence and tertiary structure with RBP. It has also been shown that STRA6 acts as a bidirectional transporter of retinol [51]. Very recently, a new candidate has been discovered: RBPR2 (RBP4-receptor 2). Structurally related to STRA6, this ubiquitous transporter is clearly expressed in the intestine, where it may play a role in dietary retinol uptake [52].

Concerning carotenoids, it has long been assumed that their intestinal absorption occurs by passive diffusion. In living unanesthetized rats, $\beta$-carotene absorption was shown to be linear between 0.5 and $11 \mathrm{mM}$. Also, an increase in the perfusate hydrogen ion concentrations (which should decrease cell membrane resistance to micelle diffusion), additions of different types of fatty acids, or an increase in the perfusate flow rate (which should diminish the thickness of the unstirred water layer) increased its absorption. Conversely, an increase in taurocholate concentration did not change it. These observations led the authors to conclude that $\beta$-carotene absorption was driven by passive diffusion [3].

However, a close look at the data obtained by Hollander and coworkers shows a saturation of absorption in the distal part of the intestine. Additionally, the hypothesis of a passive diffusion mechanism for carotenoid uptake cannot explain (i) the high inter-individual variability in absorption observed in human studies [53,54]; (ii) the isomer selectivity and the competition for absorption between carotenoids [55], or between lutein and carotenoids or vitamin, and vice versa [56,57] observed in cell models; or (iii) the competition between vitamin $\mathrm{E}$ and the carotenoid canthaxanthin described in rats [58]. Finally, the identification of the Drosophila gene ninaD encoding a class B scavenger receptor essential for carotenoid cellular distribution [59] also argues in favor of the existence of putative membrane transporters of carotenoids. 
Figure 1. Proteins involved in uptake, transport and secretion pathways of vitamin A and carotenoids across the enterocyte.

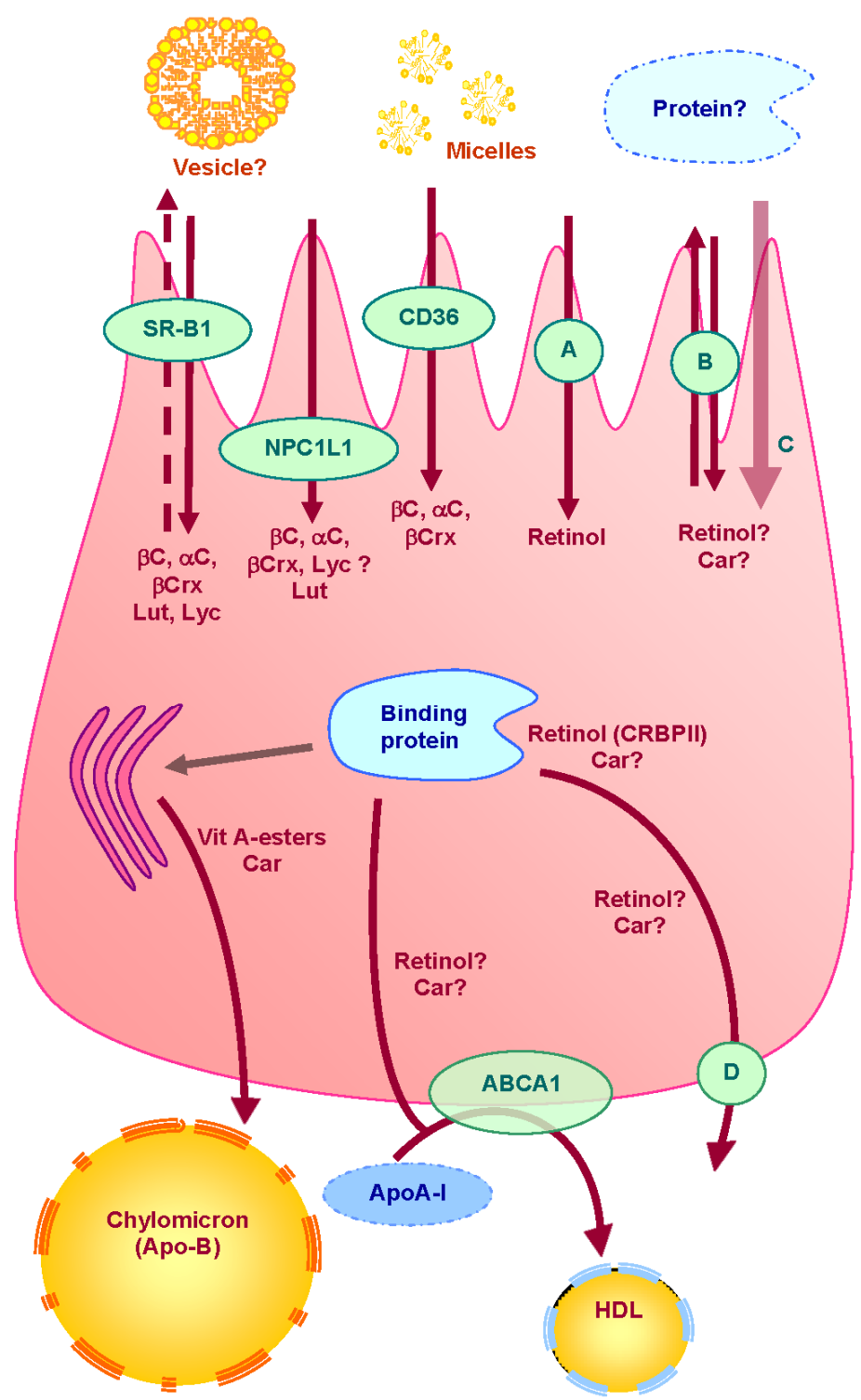

Vit $=$ vitamin $; \beta C=\beta$-carotene $; \alpha \mathrm{C}=\alpha$-carotene, $\beta \mathrm{C}=\beta$-cryptoxanthine, Lut $=$ lutein; Lyc $=$ lycopene $;$ Car $=$ carotenoids; $\mathrm{A}=$ retinol putative specific transporter; $\mathrm{B}=$ unidentified apical transporter; $\mathrm{C}=$ passive diffusion; $\mathrm{D}=$ unidentified basolateral efflux transporter; ? = putative pathway. Carotenoids are captured from mixed micelles by apical membrane transporters: SR-BI, CD36 and NPC1L1. Apical membrane proteins involved in apical uptake of retinol have not yet been identified. A fraction of vitamin A and carotenoids may then be effluxed back to the intestinal lumen via apical membrane transporters (SR-BI and possibly other transporters). Another fraction is transported to the site where they are incorporated into chylomicrons. Some proteins may be involved in intracellular transport of carotenoids, but none has been clearly identified. Conversely, CRBPII has clearly been described as involved in intracellular transport retinol. Retinyl esters and carotenoids are secreted in the lymph into chylomicrons, while a part of the more polar metabolites may be secreted by the portal route. It is suggested that free retinol can also be secreted at the basolateral side via ABCA1 (apoAI pathway). 
Several lipid transporters playing a role in carotenoid uptake by the intestinal cell have since been identified. The first one to be highlighted was the Scavenger Receptor class B type I: SR-BI. This ubiquitous $80 \mathrm{kDa}$ single-chain transmembrane glycoprotein is found on the BBM of enterocytes from the duodenum to the colon [60]. First identified as able to bind lipoproteins [61], SR-BI can also facilitate the selective entry into the cell of a large number of ligands, from free and esterified cholesterol to phospholipids and triacylglycerol hydrolysis products [62,63]. However, the effective role of SR-BI in the intestine is probably to facilitate the uptake of lipids other than cholesterol [64]. A first study performed in our laboratory identified this protein as playing a role in the intestinal uptake of the carotenoid lutein in Caco-2 cells [65]. This involvement has since been extended to other carotenoids such as $\beta$-carotene [66], zeaxanthin [67] and lycopene [68] in various other tissues. However, SR-BI does not seem to be involved in the uptake of micellar retinol [46].

Another ubiquitous scavenger receptor of interest is CD36 (Cluster Determinant 36). This other $90 \mathrm{kDa}$ single chain-membrane glycoprotein is also expressed at the BBM level of the duodenum and the jejunum [61] and displays a broad substrate specificity [69]. It is assumed to play a key role in fatty acid uptake in the intestine [70]. It was shown that lipid secretion in the lymph was decreased in CD36-deficient mice [71], as CD36 probably allows the routing of the long-chain fatty acids to the endoplasmic reticulum for chylomicron assembly in the enterocyte. Although the underlying mechanism is unknown, it may be linked to the intracellular traffic of the protein between the plasma membrane and the organelles. CD36 was involved in $\beta$-carotene uptake using transfected COS cells and mouse BBM vesicles [66], in agreement with the finding that a CD36-related protein is involved in selective carotenoid transport in Bombyx mori [72]. In addition, CD36 has been shown to be involved in both lycopene and lutein uptake in mouse 3T3-L1 adipocytes and in mouse adipose tissue cultures [73]. It is noteworthy that CD36 colocalizes with other proteins such as caveolin-1 in lipid rafts [74]. It is therefore possible that a cooperation occurs between these proteins for lipid micronutrient uptake.

Among the cholesterol membrane transporters, one of the last to be identified was NPC1L1, a $135 \mathrm{kDa}$ protein widely expressed in human tissues including the plasma membrane of the intestinal cell [75-79]. NPC1L1 has been described as the main cholesterol and phytosterol transporter in the intestine $[76,77,80]$. NPC1L1 was suggested to be involved in carotenoid intestinal uptake, as its specific inhibitor ezetimibe decreased $\alpha$ - and $\beta$-carotene uptake by $50 \%, \beta$-cryptoxanthin and lycopene uptake by $20 \%$, and lutein and zeaxanthin uptake by $7 \%$ in Caco- 2 cells [81]. Even though this result was confirmed for lutein [82], another study showed that neither ezetimibe nor a blocking antibody raised against NPC1L1 impaired lycopene absorption in the same cells [68].

No clear data are currently available on carotenoid apical efflux across the BBM of the intestinal cell. Nevertheless, as SR-BI can function in both directions in the intestine [83], and as it was shown to be involved in both vitamin D [84] and E [85] efflux throughout Caco-2 cell apical membrane, we suggest that a similar phenomenon can exist for carotenoids. It is also very likely that other transporters, such as the ATP-Binding Cassette (ABC) transporters can act as efflux pumps of lipid micronutrients through the BBM. As a matter of fact, it has been suggested that ABCG5 plays a role in the plasma response to dietary carotenoids [86]. 


\subsection{Intracellular Metabolism}

Once taken up by the enterocyte, retinol is esterified in retinyl esters by LRAT (Lecithin Retinol Acyl Transferase) and ARAT (Acyl-CoA Acyl Transferase) [87]. The use of LRAT-deficient mice indicated that this enzyme played the most crucial role regarding retinol esterification [88]. The main ester formed is retinyl palmitate, but significant amounts of retinyl oleate, linoleate, and stearate can be found in mice [89] and humans [90].

Interestingly, there is a synergy between STRA6 and LRAT expression [91], although the presence of LRAT is not strictly necessary for retinol influx into the cells [92]. We can hypothesize that such a synergy may also exist with another retinol transporter close to STRA6. If the intestinal cells express both STRA6 or a related transporter and LRAT, then they can theoretically take up more retinol than cells expressing each protein individually, the conversion of retinol into retinyl ester by LRAT within the cell maintaining the driving force for STRA6-mediated retinol uptake.

After uptake by the enterocyte, a substantial quantity of carotenoids is not metabolized (up to $40 \%$ of the dietary intake) [93]. A fraction of provitamin A carotenoids is cleaved into retinal by the cytoplasmic protein BCMO1 ( $\beta$-carotene-15,15'-monooxygenase). Retinal can then be converted to retinol and then to retinyl esters. They can also be cleaved, together with non-provitamin $\mathrm{A}$ carotenoids, into apocarotenoids by mitochondrial BCDO2 ( $\beta$-carotene- $9^{\prime}, 10^{\prime}$-dioxygenase) [94]. In order to exhibit a provitamin A activity, a carotenoid should display at least both one $\beta$-ionone ring and an appropriate methyl group in its polyene chain. Thus in theory, one molecule of $\beta$-carotene can give rise to two molecules of retinol, while $\alpha$-carotene and $\beta$-cryptoxanthine will give one retinol molecule only. In practice, $\beta$-carotene is effectively the most potent vitamin $\mathrm{A}$ precursor, $\alpha$-carotene and $\beta$-cryptoxanthine showing $30 \%$ to $50 \%$ of provitamin A activity $[95,96]$. Apparently, no cis-trans isomerization of $\beta$-carotene occurs in intestinal cells [55], suggesting that the 9-cis isomerization reported in vivo [97] occurs in the gastrointestinal lumen.

\subsection{Cytosolic Transport}

Intracellular transport of retinol (and its metabolites retinal and retinoic acid) involve retinoid-binding proteins in most tissues [98,99]. CRBPII (Cellular Retinol-Binding Protein II) is mainly expressed in the absorptive cells of the intestine and is one of the most abundant soluble proteins in the jejunum, representing up to $1 \%$ of the total enterocyte cytosolic proteins [100]. It was first shown that its mRNA expression increased in the small intestine of rats under a retinoid-deficient diet [101]. Studies using CRBPII-deficient mice then definitively acknowledged CRBPII as playing an important role in vitamin A intestinal absorption and metabolism [102,103]. The involvement of CRBPI (Cellular Retinol-Binding Protein I) cannot be ruled out, as this protein is also found in the enterocyte [104], but no mechanistic evidence is available to date. STRA6 may be able to couple to both CRBPI and CRBPII depending on the conditions. However, although CRBPII is considered to facilitate the uptake of free retinol by the enterocyte, it has been shown to couple efficiently to STRA6 for retinol efflux [92].

Concerning carotenoids, a cytosolic carotenoid-binding protein (CBP) has been identified in the midgut of the silkworm Bombyx mori [72,105]. Interestingly, the lutein-binding protein HR-LBP 
present in human retina (Human Retinal Lutein-Binding Protein) cross-reacts with antibodies raised against Bombyx mori silkworm CBP. If expressed in human enterocytes, LBP would thus be a good candidate as an intracellular transporter of xanthophylls.

Other candidates for the intracellular transport of carotenoids are the apical membrane transporters trafficking between the apical membrane and the cellular organelles. NPC1L1 has been observed in endosomes, perinuclear regions, lysosomes and mitochondria of the human intestinal cell [106,107]. CD36 has been detected in both the apical membrane and the Golgi apparatus [108]. Finally, SR-BI has also been found at the apical and basolateral membranes of enterocytes, as well as in cytoplasmic lipid droplets and in tubulovesicular membranes. Mainly localized in the microvillus membrane in the fasting state, SR-BI seems to be endocytosed after a dietary fat load [109]. Some carotenoids may bind to these apical transporters, or to membrane microdomains close to these transporters, and traffic with them within the cell to be transferred to either other intracellular transporters or to intracellular membranes.

Finally, Fatty Acid-Binding Proteins (FABPs) may be able to participate in the intracellular transport of carotenoids as they display a broad ligand specificity [110,111]. Two FABPs exhibiting a high-affinity binding of long-chain fatty acids are co-expressed in the human enterocyte: intestinal FABP (IFABP) and liver FABP (LFABP) [112,113], and it is suggested that IFABPs allow a specific trafficking of their ligands to their respective metabolic fates. Although dedicated studies are needed to verify whether IFABP and/or LFABP are involved in carotenoid metabolism, it is noteworthy that a genetic association study found that a genetic variant in IFABP was associated with fasting plasma lycopene concentrations [114].

\subsection{Basolateral Secretion}

In the postprandial period, it is assumed that the major fraction of vitamin A and carotenoids are incorporated into chylomicrons that are secreted into the lymph [115,116], vitamin A being recovered as retinyl esters, while carotenoids are recovered in their free forms [90,117]. It was shown in Caco-2 cells that only newly-synthesized retinyl esters could be incorporated into chylomicrons [47], which suggests that retinyl ester synthesis is coupled to chylomicron assembly.

Interestingly, it has been shown that in the fasting state, free retinol unassociated with lipoproteins could be secreted by Caco-2 cells [115]. In addition, in patients who do not assemble and secrete chylomicrons (abetalipoproteinemia), massive retinol supplementation can reverse retinal abnormality due to retinol deficiency [118], indicating that a pathway other than the chylomicron route may be involved in retinol absorption. Additionally, it is now clear that the intestine is also able to secrete large amounts of HDL during the postprandial period via an ABCA1 transporter-dependent pathway [119]. ABCA1 is a $240 \mathrm{kDa}$ protein playing a pivotal role in reverse cholesterol transport, although the molecular mechanisms involved in this phenomenon are still matter of debate [120]. ABCA1 is strongly expressed in the intestine [121], especially at the basolateral side of the cell [122]. Experiments performed in ABCA1-deficient mice showed that it was not significantly involved in the intestinal secretion of retinyl esters [89]. It has been suggested that it could facilitate the efflux of free retinol from intestinal cells [47]. The authors show that both glyburide (an inhibitor of ABC transporters) and SiRNA targeting complementary DNA of ABCA1 partly inhibited retinol basolateral 
efflux. However, glyburide is far from being a highly specific inhibitor [123], so this result needs further confirmation.

\section{Consequences of the Involvement of Vitamin A and Carotenoid Intestinal Transporters}

A first factor that may modulate the expression and/or activity of intestinal proteins involved in vitamin A and carotenoid absorption is vitamin A and carotenoids themselves, through a feedback regulation. For example, using both mouse models and human cell lines, it was shown that retinoic acid produced from dietary precursors induced the expression of the intestinal transcription factor ISX (Intestine-Specific Homebox) that repressed the expression of both SR-B1 and BCMO1 [124]. Another example is in Caco-2 cells, where CRBPII expression was increased after retinoic acid treatment [125]. Many transporters can also be regulated by some of their ligands other than retinoids and carotenoids. This is the case for NPC1L1 and the ATP-binding cassette proteins ABCA1, ABCG5 and ABCG8, which are downregulated under cholesterol-free high-fat diets [126]. It was also shown that heart CD36 and hepatic SR-BI expressions were regulated by dietary fat [127,128], and that CRBPII was modulated by diets containing long-chain fatty acids [101]. It is thus possible that the effect of fat on vitamin A and carotenoid absorption described in the first section is actually partly linked to a modulation of the expression of transporters involved in their absorption.

A second factor is the possible existence of genetic variants in genes encoding transport proteins that may affect vitamin A and carotenoid absorption efficiency. Genetic variations leading to modifications in the promoter region of the gene or within the amino acid sequence of the protein may affect its expression and/or activity, and thus its ability to absorb/transport its ligands. This is supported by the broad inter-individual variability observed for carotenoid assimilation [53], and by the associations found between genetic variants SR-BI and CD36 and blood concentrations of carotenoids $[129,130]$. However, these associations may be due to the effect of genetic variants on the expression or activity of the proteins in tissues other than the intestine (i.e., the liver). $\beta$-Carotene "low-converter" phenotypes, probably due to genetic variation in the BCMO1 gene, have been reported in several studies [94]. If this hypothesis is supported in the future, it may be worthwhile taking it into account to provide adequate dietary amount of vitamin $\mathrm{A}$ and carotenoid to "low responder" or "high responder" phenotypes due to different transport and/or conversion efficacy. It is also interesting to note that as some of the transporters described above are involved in the absorption of several lipid micronutrients (e.g., SR-BI participate in the absorption of carotenoids, but also of vitamin E [85] and vitamin D [84]), some subjects may be at risk of micronutrient multideficiency. Adequate recommended dietary allowances would then be a first step towards personalized nutrition based on the genetic characteristics of individuals.

\section{Conclusions}

To conclude, the full understanding of vitamin A and carotenoid absorption by the enterocyte is still in progress. Although some specific proteins such as the cytosolic CRBPII, and several non-specific transporters such as SR-BI, NPC1-L1, and ABCA1 have been identified, other transporters such as the dietary vitamin A apical membrane transporter remain to be identified. 


\section{Conflicts of Interest}

The authors declare no conflict of interest.

\section{References}

1. Gerster, H. Vitamin A-Functions, dietary requirements and safety in humans. Int. J. Vitam. Nutr. Res. 1997, 67, 71-90.

2. Hollander, D.; Muralidhara, K.S. Vitamin A1 intestinal absorption in vivo: Influence of luminal factors on transport. Am. J. Physiol. Gastrointest. Liver Physiol. 1977, 232, E471-E477.

3. Hollander, D.; Ruble, P.E. Beta-carotene intestinal absorption: Bile, fatty acid, $\mathrm{pH}$, and flow rate effects on transport. Am. J. Physiol. 1978, 235. E686-E691.

4. Hollander, D. Intestinal absorption of vitamin A, E, D, and K. J. Lab. Clin. Med. 1981, 97, 449-462.

5. Borel, P. Factors affecting intestinal absorption of highly lipophilic food microconstituents (fat-soluble vitamins, carotenoids and phytosterols). Clin. Chem. Lab. Med. 2003, 41, 979-994.

6. Martin, A. Apports Nutritionnels Conseillés Pour La Population Française, 3rd ed.; Tec \& Doc Lavoisier: Paris, France, 2001; p. 605.

7. Reboul, E.; Richelle, M.; Perrot, E.; Desmoulins-Malezet, C.; Pirisi, V.; Borel, P. Bioaccessibility of carotenoids and vitamin E from their main dietary sources. J. Agric. Food Chem. 2006, 54, 8749-8755.

8. Dhuique-Mayer, C.; Borel, P.; Reboul, E.; Caporiccio, B.; Besancon, P.; Amiot, M.J. Beta-cryptoxanthin from citrus juices: Assessment of bioaccessibility using an in vitro digestion/Caco-2 cell culture model. Br. J. Nutr. 2007, 97, 883-890.

9. Hedren, E.; Diaz, V.; Svanberg, U. Estimation of carotenoid accessibility from carrots determined by an in vitro digestion method. Eur. J. Clin. Nutr. 2002, 56, 425-430.

10. Borel, P.; Grolier, P.; Armand, M.; Partier, A.; Lafont, H.; Lairon, D.; Azais-Braesco, V. Carotenoids in biological emulsions: Solubility, surface-to-core distribution, and release from lipid droplets. J. Lipid Res. 1996, 37, 250-261.

11. Tyssandier, V.; Reboul, E.; Dumas, J.F.; Bouteloup-Demange, C.; Armand, M.; Marcand, J.; Sallas, M.; Borel, P. Processing of vegetable-borne carotenoids in the human stomach and duodenum. Am. J. Physiol. Gastrointest. Liver Physiol. 2003, 284, G913-G923.

12. Borel, P.; Pasquier, B.; Armand, M.; Tyssandier, V.; Grolier, P.; Alexandre-Gouabau, M.C.; Andre, M.; Senft, M.; Peyrot, J.; Jaussan, V.; et al. Processing of vitamin A and E in the human gastrointestinal tract. Am. J. Physiol. Gastrointest. Liver Physiol. 2001, 280, G95-G103.

13. Carrière, F.; Barrowman, J.A.; Verger, R.; Laugier, R. Secretion and contribution to lipolysis of gastric and pancreatic lipases during a test meal in humans. Gastroenterology 1993, 105, 876-888.

14. Lombardo, D.; Guy, O. Studies on the substrate specificity of a carboxyl ester hydrolase from human pancreatic juice. II. Action on cholesterol esters and lipid-soluble vitamin esters. Biochim. Biophys. Acta 1980, 611, 147-155. 
15. Zahalka, H.A.; Shee; Cheng, C.; Burton, G.W.; Ingold, K.U. Hydrolysis of stereoisomeric alpha-tocopheryl acetates catalyzed by bovine cholesterol esterase. Biochim. Biophys. Acta 1987, 921, 481-485.

16. Lauridsen, C.; Hedemann, M.S.; Jensen, S.K. Hydrolysis of tocopheryl and retinyl esters by porcine carboxyl ester hydrolase is affected by their carboxylate moiety and bile acids. J. Nutr. Biochem. 2001, 12, 219-224.

17. Breithaupt, D.E.; Bamedi, A.; Wirt, U. Carotenol fatty acid esters: Easy substrates for digestive enzymes? Comp. Biochem. Physiol. B Biochem. Mol. Biol. 2002, 132, 721-728.

18. Van Bennekum, A.M.; Li, L.; Piantedosi, R.; Shamir, R.; Vogel, S.; Fisher, E.A.; Blaner, W.S.; Harrison, E.H. Carboxyl ester lipase overexpression in rat hepatoma cells and CEL deficiency in mice have no impact on hepatic uptake or metabolism of chylomicron-retinyl ester. Biochemistry 1999, 38, 4150-4156.

19. Weng, W.; Li, L.; Van Bennekum, A.M.; Potter, S.H.; Harrison, E.H.; Blaner, W.S.; Breslow, J.L.; Fisher, E.A. Intestinal absorption of dietary cholesteryl ester is decreased but retinyl ester absorption is normal in carboxyl ester lipase knockout mice. Biochemistry 1999, 38, 4143-4149.

20. Erlanson, C.; Borgstrom, B. The identity of vitamin A esterase activity of rat pancreatic juice. Biochim. Biophys. Acta 1968, 167, 629-631.

21. Lindstrom, M.B.; Sternby, B.; Borgstrom, B. Concerted action of human carboxyl ester lipase and pancreatic lipase during lipid digestion in vitro: Importance of the physicochemical state of the substrate. Biochim. Biophys. Acta 1988, 959, 178-184.

22. Reboul, E.; Berton, A.; Moussa, M.; Kreuzer, C.; Crenon, I.; Borel, P. Pancreatic lipase and pancreatic lipase-related protein 2, but not pancreatic lipase-related protein 1, hydrolyze retinyl palmitate in physiological conditions. Biochim. Biophys. Acta 2006, 1761, 4-10.

23. Rigtrup, K.M.; Kakkad, B.; Ong, D.E. Purification and partial characterization of a retinyl ester hydrolase from the brush border of rat small intestine mucosa: Probable identity with brush border phospholipase B. Biochemistry 1994, 33, 2661-2666.

24. Rigtrup, K.M.; Mcewen, L.R.; Said, H.M.; Ong, D.E. Retinyl ester hydrolytic activity associated with human intestinal brush border membranes. Am. J. Clin. Nutr. 1994, 60, 111-116.

25. Rigtrup, K.M.; Ong, D.E. A retinyl ester hydrolase activity intrinsic to the brush border membrane of rat small intestine. Biochemistry 1992, 31, 2920-2926.

26. Levin, G.; Mokady, S. Incorporation of all-trans- or 9-cis-beta-carotene into mixed micelles in vitro. Lipids 1995, 30, 177-179.

27. Tyssandier, V.; Lyan, B.; Borel, P. Main factors governing the transfer of carotenoids from emulsion lipid droplets to micelles. Biochim. Biophys. Acta 2001, 1533, 285-292.

28. Borel, P.; Armand, M.; Pasquier, B.; Senft, M.; Dutot, G.; Melin, C.; Lafont, H.; Lairon, D. Digestion and absorption of tube-feeding emulsions with different droplet sizes and compositions in the rat. J. Parenter. Enter. Nutr. 1994, 18, 534-543.

29. Bengtsson, A.; Larsson Alminger, M.; Svanberg, U. In vitro bioaccessibility of beta-carotene from heat-processed orange-fleshed sweet potato. J. Agric. Food Chem. 2009, 57, 9693-9698.

30. Kirilenko, V.N.; Gregoriadis, G. Fat soluble vitamins in liposomes: Studies on incorporation efficiency and bile salt induced vesicle disintegration. J. Drug Target. 1993, 1, 361-368. 
31. Noy, N.; Kelleher, D.J.; Scotto, A.W. Interactions of retinol with lipid bilayers: Studies with vesicles of different radii. J. Lipid Res. 1995, 36, 375-382.

32. Perez, M.D.; Calvo, M. Interaction of b-lactoglobulin with retinol and fatty acids and its role as a possible biological function for this protein: A review. J. Dairy Sci. 1995, 78, 978-988.

33. Said, H.M.; Ong, D.E.; Shingleton, J.L. Intestinal uptake of retinol: Enhancement by bovine milk beta-lactoglobuline. Am. J. Clin. Nutr. 1989, 49, 690-694.

34. Godovac-Zimmermann, J. The Structural motif of B-Lactoglobulin and Retinol-Binding Protein: A basic framework for binding and transport of small Hydrophobic molecules. Trends Biochem. Sci. 1988, 13, 64-66.

35. Dufour, E.; Haertle, T. Binding of retinoids and beta-carotene to beta-lactoglobulin. Influence of protein modifications. Biochim. Biophys. Acta 1991, 1079, 316-320.

36. Sivakumar, B.; Reddy, V. Absorption of labelled vitamin A in children during infection. Br. $J$. Nutr. 1972, 27, 299-304.

37. O'neill, M.E.; Thurnham, D.I. Intestinal absorption of $\beta$-carotene, lycopene and lutein in men and women following a standard meal: Response curves in the triacylglycerol-rich lipoprotein fraction. Br. J. Nutr. 1998, 79, 149-159.

38. Novotny, J.A.; Dueker, S.R.; Zech, L.A.; Clifford, A.J. Compartmental analysis of the dynamics of beta-carotene metabolism in an adult volunteer. J. Lipid Res. 1995, 36, 1825-1838.

39. Van Vliet, T.; Schreurs, W.H.; van Den Berg, H. Intestinal beta-carotene absorption and cleavage in men: Response of beta-carotene and retinyl esters in the triglyceride-rich lipoprotein fraction after a single oral dose of beta-carotene. Am. J. Clin. Nutr. 1995, 62, 110-116.

40. Faulks, R.M.; Hart, D.J.; Wilson, P.D.; Scott, K.J.; Southon, S. Absorption of all-trans and 9-cis beta-carotene in human ileostomy volunteers. Clin. Sci. 1997, 93, 585-591.

41. Van Lieshout, M.; West, C.E.; van Breemen, R.B. Isotopic tracer techniques for studying the bioavailability and bioefficacy of dietary carotenoids, particularly beta-carotene, in humans: A review. Am. J. Clin. Nutr. 2003, 77, 12-28.

42. Van Loo-Bouwman, C.A.; Naber, T.H.; van Breemen, R.B.; Zhu, D.; Dicke, H.; Siebelink, E.; Hulshof, P.J.; Russel, F.G.; Schaafsma, G.; West, C.E. Vitamin A equivalency and apparent absorption of beta-carotene in ileostomy subjects using a dual-isotope dilution technique. Br. $J$. Nutr. 2010, 103, 1836-1843.

43. Drevon, C.A. Absorption, transport and metabolism of vitamin E. Free Radic. Res. Commun. 1991, 14, 229-246.

44. Traber, M.G.; Sies, H. Vitamin E in humans: Demand and delivery. Annu. Rev. Nutr. 1996, 16, 321-347.

45. Cohn, W. Bioavailability of vitamin E. Eur. J. Clin. Nutr. 1997, 51 (Suppl. 1), S80-S85.

46. Borel, P.; Lietz, G.; Goncalves, A.; Szabo De Edelenyi, F.; Lecompte, S.; Curtis, P.; Goumidi, L.; Caslake, M.J.; Miles, E.A.; Packard, C.; et al. CD36 and SR-BI are involved in cellular uptake of provitamin A carotenoids by Caco-2 and HEK cells, and some of their genetic variants are associated with plasma concentrations of these micronutrients in humans. J. Nutr. 2013, 143, 448-456.

47. During, A.; Harrison, E.H. Mechanisms of provitamin A (carotenoid) and vitamin A (retinol) transport into and out of intestinal Caco-2 cells. J. Lipid Res. 2007, 48, 2283-2294. 
48. Quick, T.C.; Ong, D.E. Vitamin A metabolism in the human intestinal caco-2 cell line. Biochemistry 1990, 29, 1116-1123.

49. Kawaguchi, R.; Yu, J.; Honda, J.; Hu, J.; Whitelegge, J.; Ping, P.; Wiita, P.; Bok, D.; Sun, H. A membrane receptor for retinol binding protein mediates cellular uptake of vitamin A. Science 2007, 315, 820-825.

50. Bouillet, P.; Sapin, V.; Chazaud, C.; Messaddeq, N.; Decimo, D.; Dolle, P.; Chambon, P. Developmental expression pattern of Stra6, a retinoic acid-responsive gene encoding a new type of membrane protein. Mech. Dev. 1997, 63, 173-186.

51. Isken, A.; Golczak, M.; Oberhauser, V.; Hunzelmann, S.; Driever, W.; Imanishi, Y.; Palczewski, K.; von Lintig, J. RBP4 disrupts vitamin A uptake homeostasis in a STRA6-deficient animal model for Matthew-Wood syndrome. Cell Metab. 2008, 7, 258-268.

52. Alapatt, P.; Guo, F.; Komanetsky, S.M.; Wang, S.; Cai, J.; Sargsyan, A.; Rodríguez Díaz, E.; Bacon, B.T.; Aryal, P.; Graham, T.E. Liver retinol transporter and receptor for serum retinol-binding protein (RBP4). J. Biol. Chem. 2013, 288, 1250-1265.

53. Borel, P.; Grolier, P.; Mekki, N.; Boirie, Y.; Rochette, Y.; Le Roy, B.; Alexandre-Gouabau, M.C.; Lairon, D.; Azais-Braesco, V. Low and high responders to pharmacological doses of beta-carotene: Proportion in the population, mechanisms involved and consequences on beta-carotene metabolism. J. Lipid Res. 1998, 39, 2250-2260.

54. Jeanes, Y.M.; Hall, W.L.; Lodge, J.K. Comparative (2)H-labelled alpha-tocopherol biokinetics in plasma, lipoproteins, erythrocytes, platelets and lymphocytes in normolipidaemic males. Br. $J$. Nutr. 2005, 94, 92-99.

55. During, A.; Hussain, M.M.; Morel, D.W.; Harrison, E.H. Carotenoid uptake and secretion by CaCo-2 cells: Beta-carotene isomer selectivity and carotenoid interactions. J. Lipid Res. 2002, 43, 1086-1095.

56. Reboul, E.; Thap, S.; Perrot, E.; Amiot, M.J.; Lairon, D.; Borel, P. Effect of the main dietary antioxidants (carotenoids, gamma-tocopherol, polyphenols, and vitamin C) on alpha-tocopherol absorption. Eur. J. Clin. Nutr. 2007, 61, 1167-1173.

57. Reboul, E.; Thap, S.; Tourniaire, F.; Andre, M.; Juhel, C.; Morange, S.; Amiot, M.J.; Lairon, D.; Borel, P. Differential effect of dietary antioxidant classes (carotenoids, polyphenols, vitamin C and vitamin E) on lutein absorption. Br. J. Nutr. 2007, 97, 440-446.

58. Hageman, S.H.; She, L.; Furr, H.C.; Clark, R.M. Excess vitamin E decreases canthaxanthin absorption in the rat. Lipids 1999, 34, 627-631.

59. Kiefer, C.; Sumser, E.; Wernet, M.F.; von Lintig, J. A class B scavenger receptor mediates the cellular uptake of carotenoids in Drosophila. Proc. Natl. Acad. Sci. USA 2002, 99, 10581-10586.

60. Lobo, M.V.; Huerta, L.; Ruiz-Velasco, N.; Teixeiro, E.; de La Cueva, P.; Celdran, A.; Martín-Hidalgo, A.; Vega, M.A.; Bragado, R. Localization of the lipid receptors CD36 and CLA-1/SR-BI in the human gastrointestinal tract: Towards the identification of receptors mediating the intestinal absorption of dietary lipids. J. Histochem. Cytochem. 2001, 49, 1253-1260.

61. Terpstra, V.; van Amersfoort, E.S.; van Velzen, A.G.; Kuiper, J.; van Berkel, T.J. Hepatic and extrahepatic scavenger receptors: Function in relation to disease. Arterioscler. Thromb. Vasc. Biol. 2000, 20, 1860-1872. 
62. Hauser, H.; Dyer, J.H.; Nandy, A.; Vega, M.A.; Werder, M.; Bieliauskaite, E.; Weber, F.E.; Compassi, S.; Gemperli, A.; Boffelli, D.; et al. Identification of a receptor mediating absorption of dietary cholesterol in the intestine. Biochemistry 1998, 37, 17843-17850.

63. Bietrix, F.; Yan, D.; Nauze, M.; Rolland, C.; Bertrand-Michel, J.; Comera, C.; Schaak, S.; Barbaras, R.; Groen, A.K.; Perret, B.; et al. Accelerated lipid absorption in mice overexpressing intestinal SR-BI. J. Biol. Chem. 2006, 281, 7214-7219.

64. Reboul, E.; Borel, P. Proteins involved in uptake, intracellular transport and basolateral secretion of fat-soluble vitamins and carotenoids by mammalian enterocytes. Prog. Lipid Res. 2011, 50, 388-402.

65. Reboul, E.; Abou, L.; Mikail, C.; Ghiringhelli, O.; Andre, M.; Portugal, H.; Jourdheuil-Rahmani, D.; Amiot, MJ.; Lairon, D.; Borel, P. Lutein transport by Caco-2 TC-7 cells occurs partly by a facilitated process involving the scavenger receptor class B type I (SR-BI). Biochem. J. 2005, 387, 455-461.

66. Van Bennekum, A.; Werder, M.; Thuahnai, S.T.; Han, C.H.; Duong, P.; Williams, D.L.; Wettstein, P.; Schulthess, G.; Phillips, M.C. Class B scavenger receptor-mediated intestinal absorption of dietary beta-carotene and cholesterol. Biochemistry 2005, 44, 4517-4525.

67. During, A.; Doraiswamy, S.; Harrison, E.H. Xanthophylls are preferentially taken up compared with beta-carotene by retinal cells via a SRBI-dependent mechanism. J. Lipid Res. 2008, 49, 1715-1724.

68. Moussa, M.; Landrier, J.F.; Reboul, E.; Ghiringhelli, O.; Comera, C.; Collet, X.; Fröhlich, K.; Böhm, V.; Borel, P. Lycopene absorption in human intestinal cells and in mice involves scavenger receptor class B type I but not Niemann-Pick C1-like 1. J. Nutr. 2008, 138, 1432-1436.

69. Tandon, N.N.; Kralisz, U.; Jamieson, G.A. Identification of glycoprotein IV (CD36) as a primary receptor for platelet-collagen adhesion. J. Biol. Chem. 1989, 264, 7576-7583.

70. Goudriaan, J.R.; Dahlmans, V.E.; Febbraio, M.; Teusink, B.; Romijn, J.A.; Havekes, L.M.; Voshol, P.J. Intestinal lipid absorption is not affected in CD36 deficient mice. Mol. Cell. Biochem. 2002, 239, 199-202.

71. Drover, V.A.; Ajmal, M.; Nassir, F.; Davidson, N.O.; Nauli, A.M.; Sahoo, D.; Tso, P.; Abumrad, N.A. CD36 deficiency impairs intestinal lipid secretion and clearance of chylomicrons from the blood. J. Clin. Investig. 2005, 115, 1290-1297.

72. Sakudoh, T.; Iizuka, T.; Narukawa, J.; Sezutsu, H.; Kobayashi, I.; Kuwazaki, S.; Banno, Y.; Kitamura, A.; Sugiyama, H.; Takada, N.; et al. A CD36-related transmembrane protein is coordinated with an intracellular lipid-binding protein in selective carotenoid transport for cocoon coloration. J. Biol. Chem. 2010, 285, 7739-7751.

73. Moussa, M.; Gouranton, E.; Gleize, B.; Yazidi, C.E.; Niot, I.; Besnard, P.; Borel, P.; Landrier, J.F. CD36 is involved in lycopene and lutein uptake by adipocytes and adipose tissue cultures. Mol. Nutr. Food Res. 2011, 55, 578-584.

74. Ring, A.; Le Lay, S.; Pohl, J.; Verkade, P.; Stremmel, W. Caveolin-1 is required for fatty acid translocase (FAT/CD36) localization and function at the plasma membrane of mouse embryonic fibroblasts. Biochim. Biophys. Acta 2006, 1761, 416-423. 
75. Davies, J.P.; Levy, B.; Ioannou, Y.A. Evidence for a Niemann-pick C (NPC) gene family: Identification and characterization of NPC1L1. Genomics 2000, 65, 137-145.

76. Altmann, S.W.; Davis, H.R., Jr.; Zhu, L.J.; Yao, X.; Hoos, L.M.; Tetzloff, G.; Iyer, S.P.; Maguire, M.; Golovko, A.; Zeng, M.; et al. Niemann-Pick C1 Like 1 protein is critical for intestinal cholesterol absorption. Science 2004, 303, 1201-1204.

77. Davies, J.P.; Scott, C.; Oishi, K.; Liapis, A.; Ioannou, Y.A. Inactivation of NPC1L1 causes multiple lipid transport defects and protects against diet-induced hypercholesterolemia. J. Biol. Chem. 2005, 280, 12710-12720.

78. Garcia-Calvo, M.; Lisnock, J.; Bull, H.G.; Hawes, B.E.; Burnett, D.A.; Braun, M.P.; Crona, J.H.; Davis, H.R., Jr.; Dean, D.C.; Detmers, P.A.; et al. The target of ezetimibe is Niemann-Pick C1-Like 1 (NPC1L1). Proc. Natl. Acad. Sci. USA 2005, 102, 8132-8137.

79. Duval, C.; Touche, V.; Tailleux, A.; Fruchart, J.C.; Fievet, C.; Clavey, V.; Staels, B.; Lestavel, S. Niemann-Pick C1 like 1 gene expression is down-regulated by LXR activators in the intestine. Biochem. Biophys. Res. Commun. 2006, 340, 1259-1263.

80. Davis, H.R., Jr.; Zhu, L.J.; Hoos, L.M.; Tetzloff, G.; Maguire, M.; Liu, J.; Yao, X.; Iyer, S.P.; Lam, M.H.; Lund, E.G.; et al. Niemann-Pick C1 Like 1 (NPC1L1) is the intestinal phytosterol and cholesterol transporter and a key modulator of whole-body cholesterol homeostasis. J. Biol. Chem. 2004, 279, 33586-33592.

81. During, A.; Dawson, H.D.; Harrison, E.H. Carotenoid transport is decreased and expression of the lipid transporters SR-BI, NPC1L1, and ABCA1 is downregulated in Caco-2 cells treated with ezetimibe. J. Nutr. 2005, 135, 2305-2312.

82. Sato, Y.; Suzuki, R.; Kobayashi, M.; Itagaki, S.; Hirano, T.; Noda, T.; Mizuno, S.; Sugawara, M.; Iseki, K. Involvement of cholesterol membrane transporter Niemann-Pick C1-like 1 in the intestinal absorption of lutein. J. Pharm. Pharm. Sci. 2012, 15, 256-264.

83. Cai, L.; Eckhardt, E.R.; Shi, W.; Zhao, Z.; Nasser, M.; de Villiers, W.J.; van der Westhuyzen, D.R. Scavenger receptor class B type I reduces cholesterol absorption in cultured enterocyte CaCo-2 cells. J. Lipid Res. 2004, 45, 253-262.

84. Reboul, E.; Goncalves, A.; Comera, C.; Bott, R.; Nowicki, M.; Landrier, J.F.; Jourdheuil-Rahmani, D.; Dufour, C.; Collet, X.; Borel, P. Vitamin D intestinal absorption is not a simple passive diffusion: Evidences for involvement of cholesterol transporters. Mol. Nutr. Food Res. 2011, 55, 691-702.

85. Reboul, E.; Klein, A.; Bietrix, F.; Gleize, B.; Malezet-Desmoulins, C.; Schneider, M.; Margotat, A.; Lagrost, L.; Collet, X.; Borel, P. Scavenger receptor class B type I (SR-BI) is involved in vitamin E transport across the enterocyte. J. Biol. Chem. 2006, 281, 4739-4745.

86. Herron, K.L.; Mcgrane, M.M.; Waters, D.; Lofgren, I.E.; Clark, R.M.; Ordovas, J.M.; Fernandez, M.L. The ABCG5 polymorphism contributes to individual responses to dietary cholesterol and carotenoids in eggs. J. Nutr. 2006, 136, 1161-1165.

87. Harrison, E.H. Mechanisms of digestion and absorption of dietary vitamin A. Annu. Rev. Nutr. 2005, 25, 87-103. 
88. Batten, M.L.; Imanishi, Y.; Maeda, T.; Tu, D.C.; Moise, A.R.; Bronson, D.; Possin, D.; Van Gelder, R.N.; Baehr, W.; Palczewski, K. Lecithin-retinol acyltransferase is essential for accumulation of all-trans-retinyl esters in the eye and in the liver. J. Biol. Chem. 2004, 279, 10422-10432.

89. Reboul, E.; Trompier, D.; Moussa, M.; Klein, A.; Landrier, J.F.; Chimini, G.; Borel, P. ATP-binding cassette transporter A1 is significantly involved in the intestinal absorption of alpha- and gamma-tocopherol but not in that of retinyl palmitate in mice. Am. J. Clin. Nutr. 2009, 89, 177-184.

90. Sauvant, P.; Mekki, N.; Charbonnier, M.; Portugal, H.; Lairon, D.; Borel, P. Amounts and types of fatty acids in meals affect the pattern of retinoids secreted in human chylomicrons after a high-dose preformed vitamin A intake. Metabolism 2003, 52, 514-519.

91. Amengual, J.; Golczak, M.; Palczewski, K.; von Lintig, J. Lecithin: Retinol acyltransferase is critical for cellular uptake of vitamin A from serum retinol-binding protein. J. Biol. Chem. 2012, 287, 24216-24227.

92. Kawaguchi, R.; Zhong, M.; Kassai, M.; Ter-Stepanian, M.; Sun, H. STRA6-catalyzed vitamin A influx, efflux, and exchange. J. Membr. Biol. 2012, 245, 731-745.

93. Castenmiller, J.J.M.; West, C.E. Bioavailability and bioconversion of carotenoids. Annu. Rev. Nutr. 1998, 18, 19-38.

94. Lobo, G.P.; Amengual, J.; Palczewski, G.; Babino, D.; von Lintig, J. Carotenoid-oxygenases: Key players for carotenoid function and homeostasis in mammalian biology. Biochim. Biophys. Acta 2011, 1821, 78-81.

95. Bauernfeind, J.C. Carotenoid vitamin A precursors and analogs in foods and feeds. J. Agric. Food Chem. 1972, 20, 456-473.

96. Van Vliet, T.; Vanschaik, F.; Schreurs, W.H.P.; van Den Berg, H. In vitro measurement of beta-carotene cleavage activity: Methodological considerations and the effect of other carotenoids on beta-carotene cleavage. Int. J. Vitam. Nutr. Res. 1996, 66, 77-85.

97. You, C.S.; Parker, R.S.; Goodman, K.J.; Swanson, J.E.; Corso, T.N. Evidence of cis-trans isomerization of 9-cis-beta-carotene during absorption in humans. Am. J. Clin. Nutr. 1996, 64, 177-183.

98. Noy, N. Retinoid-binding proteins: Mediators of retinoid action. Biochem. J. 2000, 348, 481-495.

99. Napoli, J.L. Retinoic acid: Its biosynthesis and metabolism. Prog. Nucleic Acid Res. Mol. Biol. 1999, 63, 139-188.

100. Crow, J.A.; Ong, D.E. Cell-specific immunohistochemical localization of a cellular retinol-binding protein (type two) in the small intestine of rat. Proc. Natl. Acad. Sci. USA 1985, 82, 4707-4711.

101. Suruga, K.; Suzuki, R.; Goda, T.; Takase, S. Unsaturated fatty acids regulate gene expression of cellular retinol-binding protein, type II in rat jejunum. J. Nutr. 1995, 125, 2039-2044.

102. E, X.; Zhang, L.; Lu, J.; Tso, P.; Blaner, W.S.; Levin, M.S.; Li, E. Increased neonatal mortality in mice lacking cellular retinol-binding protein II. J. Biol. Chem. 2002, 277, 36617-36623. 
103. Wongsiriroj, N.; Piantedosi, R.; Palczewski, K.; Goldberg, I.J.; Johnston, T.P.; Li, E.; Blaner, W.S. The molecular basis of retinoid absorption: A genetic dissection. J. Biol. Chem. 2008, 283, 13510-13519.

104. Uchio, K.; Tuchweber, B.; Manabe, N.; Gabbiani, G.; Rosenbaum, J.; Desmouliere, A. Cellular retinol-binding protein-1 expression and modulation during in vivo and in vitro myofibroblastic differentiation of rat hepatic stellate cells and portal fibroblasts. Lab. Investig. 2002, 82, 619-628.

105. Tabunoki, H.; Sugiyama, H.; Tanaka, Y.; Fujii, H.; Banno, Y.; Jouni, Z.E.; Kobayashi, M.; Sato, R.; Maekawa, H.; Tsuchida, K. Isolation, characterization, and cDNA sequence of a carotenoid binding protein from the silk gland of Bombyx mori larvae. J. Biol. Chem. 2002, 277, 32133-32140.

106. Yu, L.; Bharadwaj, S.; Brown, J.M.; Ma, Y.; Du, W.; Davis, M.A.; Michaely, P.; Liu, P.; Willingham, M.C.; Rudel, L.L. Cholesterol-regulated translocation of NPC1L1 to the cell surface facilitates free cholesterol uptake. J. Biol. Chem. 2006, 281, 6616-6624.

107. Sane, A.T.; Sinnett, D.; Delvin, E.; Bendayan, M.; Marcil, V.; Menard, D.; Menard, D.; Beaulieu, J.F.; Levy, E. Localization and role of NPC1L1 in cholesterol absorption in human intestine. J. Lipid Res. 2006, 47, 2112-2120.

108. Pohl, J.; Ring, A.; Korkmaz, U.; Ehehalt, R.; Stremmel, W. FAT/CD36-mediated long-chain fatty acid uptake in adipocytes requires plasma membrane rafts. Mol. Biol. Cell 2005, 16, 24-31.

109. Hansen, G.H.; Niels-Christiansen, L.L.; Immerdal, L.; Danielsen, E.M. Scavenger receptor class B type I (SR-BI) in pig enterocytes: Trafficking from the brush border to lipid droplets during fat absorption. Gut 2003, 52, 1424-1431.

110. Velkov, T.; Lim, M.L.; Horne, J.; Simpson, J.S.; Porter, C.J.; Scanlon, M.J. Characterization of lipophilic drug binding to rat intestinal fatty acid binding protein. Mol. Cell. Biochem. 2009, 326, 87-95.

111. Chuang, S.; Velkov, T.; Horne, J.; Porter, C.J.; Scanlon, M.J. Characterization of the drug binding specificity of rat liver fatty acid binding protein. J. Med. Chem. 2008, 51, 3755-3764.

112. Besnard, P.; Niot, I.; Poirier, H.; Clement, L.; Bernard, A. New insights into the fatty acid-binding protein (FABP) family in the small intestine. Mol. Cell. Biochem. 2002, 239, 139-147.

113. Hanhoff, T.; Lucke, C.; Spener, F. Insights into binding of fatty acids by fatty acid binding proteins. Mol. Cell. Biochem. 2002, 239, 45-54.

114. Borel, P.; Moussa, M.; Reboul, E.; Lyan, B.; Defoort, C.; Vincent-Baudry, S.; Maillot, M.; Gastaldi, M.; Darmon, M.; Portugal, H.; et al. Human fasting plasma concentrations of vitamin E and carotenoids, and their association with genetic variants in apo C-III, cholesteryl ester transfer protein, hepatic lipase, intestinal fatty acid binding protein and microsomal triacylglycerol transfer protein. Br. J. Nutr. 2009, 101, 680-687.

115. Nayak, N.; Harrison, E.H.; Hussain, M.M. Retinyl ester secretion by intestinal cells: A specific and regulated process dependent on assembly and secretion of chylomicrons. J. Lipid Res. 2001, 42, 272-280.

116. Hussain, M.M.; Fatma, S.; Pan, X.; Iqbal, J. Intestinal lipoprotein assembly. Curr. Opin. Lipidol. 2005, 16, 281-285.

117. Huang, H.S.; Goodman, D.S. Intestinal absorbtion and metabolism of c-labeled viatamin a alcohol and b-carotene in the rat. J. Biol. Chem. 1965, 240, 2839-2844. 
118. Gouras, P.; Carr, R.E.; Gunkel, R.D. Retinitis pigmentosa in abetalipoproteinemia: Effects of vitamin A. Investig. Ophthalmol. 1971, 10, 784-793.

119. Brunham, L.R.; Kruit, J.K.; Iqbal, J.; Fievet, C.; Timmins, J.M.; Pape, T.D.; Coburn, B.A.; Bissada, N.; Staels, B.; Groen, A.K.; et al. Intestinal ABCA1 directly contributes to HDL biogenesis in vivo. J. Clin. Investig. 2006, 116, 1052-1062.

120. Reboul, E.; Dyka, F.M.; Quazi, F.; Molday, R.S. Cholesterol transport via ABCA1: New insights from solid-phase binding assay. Biochimie 2013, 95, 957-961.

121. Drobnik, W.; Lindenthal, B.; Lieser, B.; Ritter, M.; Weber, T.C.; Liebisch, G.; Giesa, U.; Igel, M.; Borsukova, H.; Buchler, C.; et al. ATP-Binding Cassette transporter A1 (ABCA1) affects total body sterol metabolism. Gastroenterology 2001, 120, 1203-1211.

122. Mulligan, J.D.; Flowers, M.T.; Tebon, A.; Bitgood, J.J.; Wellington, C.; Hayden, M.R.; Attie, A.D. ABCA1 is essential for efficient basolateral cholesterol efflux during the absorption of dietary cholesterol in chickens. J. Biol. Chem. 2003, 278, 13356-13366.

123. Nieland, T.J.; Chroni, A.; Fitzgerald, M.L.; Maliga, Z.; Zannis, V.I.; Kirchhausen, T.; Krieger, M. Cross-inhibition of SR-BI- and ABCA1-mediated cholesterol transport by the small molecules BLT-4 and glyburide. J. Lipid Res. 2004, 45, 1256-1265.

124. Lobo, G.P.; Hessel, S.; Eichinger, A.; Noy, N.; Moise, A.R.; Wyss, A.; Palczewski, K.; von Lintig, J. ISX is a retinoic acid-sensitive gatekeeper that controls intestinal beta,betacarotene absorption and vitamin A production. FASEB J. 2010, 24, 1656-1666.

125. Levin, M.S.; Davis, A.E. Retinoic acid increases cellular retinol binding protein II mRNA and retinol uptake in the human intestinal Caco-2 cell line. J. Nutr. 1997, 127, 13-17.

126. De Vogel-Van Den Bosch, H.M.; de Wit, N.J.; Hooiveld, G.J.; Vermeulen, H.; van Der Veen, J.N.; Houten, S.M.; Kuipers, F.; Muller, M.; van der Meer, R. A cholesterol-free, high-fat diet suppresses gene expression of cholesterol transporters in murine small intestine. Am. J. Physiol. Gastrointest. Liver Physiol. 2008, 294, G1171-G1180.

127. Greenwalt, D.E.; Scheck, S.H.; Rhinehart-Jones, T. Heart CD36 expression is increased in murine models of diabetes and in mice fed a high fat diet. J. Clin. Investig. 1995, 96, 1382-1388.

128. Spady, D.K.; Kearney, D.M.; Hobb, H.H. Polyunsaturated fatty acids up-regulate hepatic scavenger receptor B1 (SR-BI) expression and HDL cholesteryl ester uptake in the hamster. J. Lipid Res. 1999, 40, 1384-1394.

129. Borel, P.; Moussa, M.; Reboul, E.; Lyan, B.; Defoort, C.; Vincent-Baudry, S.; Maillot, M.; Gastaldi, M.; Darmon, M.; Portugal, H.; et al. Human plasma levels of vitamin E and carotenoids are associated with genetic polymorphisms in genes involved in lipid metabolism. J. Nutr. 2007, 137, 2653-2659.

130. Borel, P.; de Edelenyi, F.S.; Vincent-Baudry, S.; Malezet-Desmoulin, C.; Margotat, A.; Lyan, B.; Gorrand, J.M.; Meunier, N.; Drouault-Holowacz, S.; Bieuvelet, S. Genetic variants in BCMO1 and CD36 are associated with plasma lutein concentrations and macular pigment optical density in humans. Ann. Med. 2010, 43, 47-59.

(C) 2013 by the authors; licensee MDPI, Basel, Switzerland. This article is an open access article distributed under the terms and conditions of the Creative Commons Attribution license (http://creativecommons.org/licenses/by/3.0/). 